\title{
Author Correction: BRCA1-regulated RRM2 expression protects glioblastoma cells from endogenous replication stress and promotes tumorigenicity
}

Rikke D. Rasmussen', Madhavsai K. Gajjar', Lucie Tuckova², Kamilla E. Jensen', Apolinar Maya-Mendoza ${ }^{3}$, Camilla B. Holst ${ }^{4}$, Kjeld Møllgård ${ }^{4}$, Jane S. Rasmussen ${ }^{5}$, Jannick Brennum ${ }^{5}$, Jiri Bartek Jr ${ }^{5,6}$, Martin Syrucek ${ }^{7}$, Eva Sedlakova ${ }^{2}$, Klaus K. Andersen ${ }^{8}$, Marie H. Frederiksen ${ }^{8}$, Jiri Bartek ${ }^{3,9}$ \& Petra Hamerlik 1,10

Correction to: Nature Communications; https://doi.org/10.1038/ncomms13398; published online 15 November 2016

This Article contains an error in the spelling of the author Kjeld Møllgård, which is incorrectly given as Kjeld Møllgaard. The error has not been fixed in the original PDF and HTML versions of the Article.

Published online: 19 December 2018

(c) Open Access This article is licensed under a Creative Commons Attribution 4.0 International License, which permits use, sharing, adaptation, distribution and reproduction in any medium or format, as long as you give appropriate credit to the original author(s) and the source, provide a link to the Creative Commons license, and indicate if changes were made. The images or other third party material in this article are included in the article's Creative Commons license, unless indicated otherwise in a credit line to the material. If material is not included in the article's Creative Commons license and your intended use is not permitted by statutory regulation or exceeds the permitted use, you will need to obtain permission directly from the copyright holder. To view a copy of this license, visit http://creativecommons.org/licenses/by/4.0/.

(C) The Author(s) 2018

\footnotetext{
${ }^{1}$ Brain Tumor Biology, Danish Cancer Society Research Center, Strandboulevarden 49, Copenhagen DK-2100, Denmark. ${ }^{2}$ Department of Clinical and Molecular Pathology, Faculty of Medicine and Dentistry, Palacky University and University Hospital Olomouc, Hnevotinska 3, Olomouc 77515, Czech Republic. ${ }^{3}$ Genome Integrity Unit, Danish Cancer Society Research Center, Strandboulevarden 49, Copenhagen DK-2100, Denmark. ${ }^{4}$ Department of Cellular and Molecular Medicine, Faculty of Health and Medical Sciences, University of Copenhagen, Blegdamsvej 3, Copenhagen 2200-DK, Denmark. ${ }^{5}$ Department of Neurosurgery, Copenhagen University Hospital, Blegdamsvej 9, Copenhagen DK-2100, Denmark. ${ }^{6}$ Department of Medicine, Unit of Microbial Pathogenesis, Karolinska Institutet and Department of Neurosurgery, Karolinska University Hospital, Solna 171 76, Stockholm, Sweden. ${ }^{7}$ Department of Pathology, Hospital Na Homolce, Roentgenova 2, 15030 Praha 5, Czech Republic. ${ }^{8}$ Statistics, Bioinformatics and Registry Unit, Danish Cancer Society Research Center, Strandboulevarden 49, Copenhagen DK-2100, Denmark. ${ }^{9}$ Division of Translational Medicine and Chemical Biology, Department of Medical Biochemistry and Biophysics, Science for Life Laboratory, Karolinska Institute, Scheeles vag 2, Stockholm 17177, Sweden. ${ }^{10}$ Department of Radiation Biology, Copenhagen University Hospital, Blegdamsvej 9, Copenhagen 2100-DK, Denmark. Correspondence and requests for materials should be addressed to P.H. (email: pkn@cancer.dk)
} 